\title{
MODERNISASI SISTEM KOMPENSASI PADA KINERJA KARYAWAN PT ANGKASA PURA II
}

\author{
Dede Irfan Maulana Yusuf ${ }^{1}$, Tiara Rismayanti ${ }^{2}$, Thameliya Gemmy Supardi ${ }^{3}$, \\ Sofia Sifa Maulidina ${ }^{4}$, Siti nur ilma Mutiara ${ }^{5}$, Sunengsih ${ }^{6}$, Ruhenda Lesmana Wijaya \\ 1,2,3,4,5,6 Universitas Islam Negeri Sunan Gunung Djati Bandung \\ E-mail: irfandede360@gmail.com
}

\begin{abstract}
Abstrak
Dalam era globalisasi saat ini sangat diperlukan SDM yang berkualitas karena maju mundurnya suatu perusahaan sangat bergantung pada kualitas SDM atau karyawannya, oleh karena itu pengelolaan sumber daya manusia harus dilakukan secara professional agar terwujudnya keseimbangan antara kebutuhan pegawai dan tuntutan serta kemampuan perusahaan. Pemberian kompensasi dalam perusahaan harus diatur dengan baik sehingga dapat diterima oleh kedua belah pihak dengan harapan dapat menjamin kepuasan karyawan yang pada nantinya perusahaan dapat mencapai tingkat kinerja yang diinginkan. Penelitian ini dilakukan di PT. Angkasa Pura II (Persero) bertujuan untuk mengetahui modernisasi sistem kompensasi yang diberikan perusahaan agar kinerja karyawannya dapat meningkat. Adapun metode analisis data dalam penelitian ini menggunakan pendekatan deskriptif kualitatif dengan teknik pengumpulan data yang diperoleh dari laporan tahunan perusahaan tahun 2018 dan 2019 yang sudah dipublikasikan di website PT Angkasa Pura II (Persero). Berdasarkan analisis yang dilakukan pada PT Angkasa Pura II (Persero), dapat diketahui system kompensasi PT Angkasa Pura II (Persero) pada karyawannya meliputi Fixed Compensation, Variable Compensation, Benefit, Ketenagakerjaan, Non Cash Benefit. Selain itu adanya program dana pensiun bagi karyawan usia 56 tahun PT Angkasa Pura II (Persero) menyiapkan pelatihan wirausaha dan purna bakti. Adapun penilaian kinerja karyawan pada PT Angkasa Pura II (Persero) dapat dikatakan baik karena pergerakan pesawat, arus penumpang dan kargo pada tahun 2019 menunjukan peningkatan dari tahun sebelumnya.
\end{abstract}

Kata Kunci : Sistem, Kompensasi, dan Kinerja.

\section{Abstract}

In the current era of globalization, highly qualified human resources are needed because the back and forth of a company is very dependent on the quality of its human resources or employees, therefore human resource management must be done professionally in order to create a balance between employee needs and the demands and capabilities of the company. The provision of compensation in the company must be regulated properly so that it can be accepted by both parties in the hope that it can guarantee employee satisfaction that in the future the company can achieve the desired level of performance. This research was conducted at PT. Angkasa Pura II (Persero) aims to determine the modernization of the compensation system provided by the company so that the performance of its employees can improve. The data analysis method in this study uses a qualitative descriptive approach with data collection techniques obtained from the company's annual reports in 2018 and 2019 which have been published on the website of PT Angkasa Pura II (Persero). Based on an analysis conducted at PT Angkasa Pura II (Persero), it can be seen that the compensation system of PT Angkasa Pura II (Persero) for its employees includes Fixed Compensation, Variable Compensation, Benefits, Employment, Non Cash Benefit. In addition, there is a 
pension program for employees aged 56 years PT Angkasa Pura II (Persero) to prepare entrepreneurship and retirement training. The employee performance appraisal at PT Angkasa Pura II (Persero) can be said to be good because aircraft movements, passenger flows and cargo in 2019 showed an increase from the previous year.

Keywords: System, Compensation, and Performance.

\section{A. PENDAHULUAN}

Untuk menghadapi persaingan usaha yang ada saat ini, perusahaan dituntut untuk menciptakan kinerja karyawan yang tinggi untuk melakukan pengembangan usaha. Keberhasilan perusahaan dipengaruhi oleh beberapa faktor, salah satu faktor penting adalah sumber daya manusia, karena sumber daya manusia adalah pelaku dari keseluruhan tingkat perencanaan sampai evaluasi pada suatu perusahaan (Suwati, 2013). Tercapainya tujuan perusahaan tidak hanya tergantung pada peralatan-peralatan modern tetapi tergantung terhadap manusia yang melaksanakan pekerjaan tersebut. Setiap organisasi atau perusahaan akan selalu berusaha meningkatkan kinerja karyawan demi tercapainya tujuan dari perusahaan dan organisasi tersebut.

Industri kebandaraan di Indonesia dilakukan oleh dua perusahaan Negara (BUMN) yaitu PT. Angkasa Pura I dan II. Kedua perusahaan tersebut masingmasing memiliki wilayah operasional yang ditentukan oleh pemerintah. Untuk wilayah Indonesia bagian timur dikelola PT. Angkasa Pura I dan wilayah barat dikelola PT. Angkasa Pura II. PT. Angkasa Pura II (persero), merupakan salah satu perusahaan Badan Usaha Milik Negara (BUMN), yang khusus menangani jasa pelayanan pada transportasi penerbangan yakni berupa bandar udara yang merupakan suatu lapangan terbang yang digunakan untuk mendarat dan lepas landasnya pesawat terbang. Naik turun penumpang dan bongkar muat kargo dan pos serta dilengkapi dengan fasilitas keselamatan penerbangan dan sebagai perpindahan antar moda transportasi. Bandara sebagai komponen penting dalam transportasi udara merupakan mata rantai yang vital dalam sistem transportasi antar moda. Pengelolaan Bandara bukan saja harus mampu mengikuti kemajuan teknologi sarana angkutan udara tetapi juga harus mengantisipasi perkembangan bisnis untuk masa mendatang. Untuk mendapatkan hasil operasional yang maksimal dan optimal, perusahaan perlu melaksanakan program program yang berhubungan dengan kegiatan operasionalnya yaitu untuk dapat membangkitkan dan meningkatkan kinerja dari karyawan agar dapat melaksanakan rencana kerja dan program program kerja perusahaan. untuk meningkatkan kinerja dari karyawan, salah satu cara yang harus dilakukan oleh perusahaan adalah memberikan motivasi kepada karyawan untuk dapat membangkitkan gairah kerja dari karyawan yang ada diperusahaan. Selain itu perusahaan harus memberikan 
kompensasi yang sesuai dengan karyawan sebagai penambah semangat dari karyawan untuk dapat berkerja secara efektif dan efeisien sesuai dengan yang diinginkan oleh perusahaan.

Kompensasi merupakan suatu yang diterima karyawan sebagai pengganti kontribusi jasa mereka kepada organisasi. Untuk menyusun sistem pemberian kompensasi yang adil, manajemen perlu melakukan "evaluasi pekerjaan". Dengan evaluasi, manajemen berupaya mempertimbangkan dan mengukur masukan karyawan (ketrampilan, usaha, tanggung jawab dan sebagainya) untukmenetapkan kinerja minimum dan merubah ukuran dalam satuan uang. Kompensasi juga merupakan pendorong utlama karyawan untuk bekerja, karena dengan kompensasi berupa Financial para karyawan dapat memenuhi kebutuhannya. Sehingga kompensasi berpengaruh terhadap kinerja karyawan.

Berdasarkan latar belakang yang telah dikemukakan diatas, maka peneliti tertarik melakukan mengenai Modernisasi Sistem Kompensasi terhadap Kinerja Karyawan pada PT.Angkasa Pura II.

\section{RUMUSAN MASALAH}

Berdasarkan latar belakang masalah diatas,maka permasalahan yang dapat dirumuskan dalam penelitian ini adalah sebagai berikut "Bagaimana modernisasi sistem Kompensasi terhadap Kinerja Karyawan pada PT.Angkasa Pura II ?

\section{TUJUAN DAN MANFAAT PENELITIAN}

\section{Tujuan penelitian}

1. Untuk mengetahui pemberian kompensasi yang diberikan kepada karyawan pada PT. Angkasa Pura II.

2. Untuk mengetahui tingkat kinerja karyawan pada PT. Angkasa Pura II.

3. Untuk mengetahui pengaruh kompensasi terhadap kinerja karyawan pada PT. Angkasa Pura II.

4. Untuk mengetahui pengaruh motivasi terhadap kinerja karyawan pada PT. Angkasa Pura II.

5. Untuk mengetahui modernisasi pemberian kompensasi dan motivasi kerja terhadap kinerja karyawan pada PT. Angkasa Pura II.

\section{Manfaat Penelitian}

1. Bagi Penulis

Menambah pengetahuan dan wawasan penulis mengenai pengaruh antara motivasi 
dan kompensasi dengan kinerja karyawan di PT. Angkasa Pura II. Selain itu, penelitian ini dimaksudkan pula sebagai syarat akademik untuk memperoleh gelar Sarjana Manajemen pada Universitas Sunan Gunung Djati Bandung.

2. Bagi Perusahaan

Hasil penelitian ini dapat digunakan sebagai bahan petimbangan dan masukan untuk perusahaan dalam merancang bagaimana pemberian motivasi dan kompensasi yang bermanfaat kepada karyawannya, sehingga kinerja karyawan menjadi meningkat dan lebih baik serta tujuan perusahaan akan tercapai.

3. Bagi Institusi Pendidikan (UIN Bandung)

Hasil penelitian ini bisa digunakan sebagai tambahan pustaka yang nantinya dapat berguna bagi Mahasiswa bila sewaktu-waktu membutuhkan, serta dapat jadikan perbandingan dalam penelitian di masa yang akan datang.

\section{Kerangka Teori}

\section{Sumber Daya Manusia}

Menurut Sayuti Hasibuan (2000:3), sumber daya manusia adalah semua manusia yang terlibat didalam suatu organisasi dalam mengupayakan terwujudnya tujuan organisasi tersebut Nawawi (2003:37) membagi pengertian SDM menjadi dua, yaitu pengertian secara makro dan secara mikro. Pengertian SDM secara makro adalah semua manusia sebagai penduduk atau warga negara suatu negara atau dalam batas wilayah tertentu yang sudah memasuki usia angkatan kerja, baik yang sudah maupun belum memperoleh pekerjaan (lapangan kerja). Pengertian SDM dalam arti mikro secara sederhana adalah manusia atau orang yang bekerja atau enjadi anggota suatu organisasi yang disebut personil, pegawai, karyawan, pekerja, tenaga kerja, dll.

\section{Sistem}

Pengertian sistem menurut Romney dan Steinbart (2015:3): Sistem adalah rangkaian dari dua atau lebih komponen-komponen yang saling berhubungan, yang berinteraksi untuk mencapai suatu tujuan.Sebagian besar sistem terdiridari subsistem yang lebih kecil yang mendukung sistem yang lebih besar.

Pengertian sistem menurut Anastasia Diana \& Lilis Setiawati (2011:3), Sistem merupakan "serangkaian bagian yang saling tergantung dan bekerja sama untuk mencapai tujuantertentu".

Definisi sistem menurut Mulyadi (2016:5), Sistem adalah "suatu jaringan prosedur yang dibuat menurut pola yang terpadu untuk melaksanakan kegiatan pokok perusahaan”. 
Berdasarkan pengertian diatas dapat disimpulkan bahwa sistem adalah kumpulan dari komponen-komponen yang saling berkaitan satu dengan yang lain untuk mencapai tujuan dalam melaksanakan suatu kegiatan pokok perusahaan.

\section{Kompensasi}

Kompensasi adalah semua pendapatan yang diterima karyawan berbentuk uang, barang langsung atau tidak langsung yang merupakan bentuk biaya yang harus dikeluarkan perusahaan dengan harapan memperoleh imbalan berupa prestasi kerja dari karyawan (Hasibuan,2012). Kompensasi menurut Hadirja dalam Suwati (2013) adalah keseluruhan balas jasa yang diterima pegawai sebagai akibat pelaksanaan pekerjaan di organisasi dalam bentuk uang atau yang lainnya yang dapat berupa gaji, upah, bonus, insentif, tunjangan kesehatan, tunjangan hari raya, uang makan, uang cuti dan lain-lain.

Sedangkan menurut Garry Dessler (dalam kunartinah 2012) definisi kompensasi adalah segala bentuk penggajian atau ganjaran yang mengalir kepada pegawai dan timbul dari kepegawaiannya Ada tiga indikator untuk menilai kompensasi menurut Simamora (2004:442).

a. Puas terhadap Gaji

Hak yang diterima oleh karyawan karena kompensasinya terhadap perusahaan.

b. Puas terhadap Fasilitas

Kompensasi yang diberikan kepada karyawan sebagai penunjang kelancaran untuk bekerja dan memotivasi karyawan agar semangat bekerja.

c. Puas terhadap Tunjangan

Kompensasi tambahan yang diberikan berdasarkan kebijakan perusahaan terhadap semua karyawan dalam usaha meningkatkan kesejahteraan karyawan.

\section{Kinerja karyawan}

Setiap karyawan dituntut untuk memberikan kontribusi positif melalui kinerja yang baik, mengingat kinerja organisasi tergantung terhadap kinerja karyawannya. Kinerja menurut mangkunegara (2005:67) adalah hasil kerja secara kualitas dan kuantitas yang dicapai oleh seorang karyawan dalam melaksanakan tugasnya sesuai dengan tanggung jawab yang diberikan kepadanya. Selanjutnya definisi kinerja menurut Bernandin \& Russell yang dikutip Oleh Gomez (2006:135) adalah catatan yang dihasilkan dari fungsi suatu pekerjaan tertentu atau kegiatan selama periode waktu tertentu. Menurut Bangun (2012:233) indicator kinerja karyawan ada 5 yakni: 
1. Jumlah pekerjaan

Jumlah pekerjaan yang dihasilkan individu atau kelompok sebagai persyaratan yang menjadi standar pekerjaan. Setiap pekerjaan memiliki persyaratan yang berbeda sehingga menuntut karyawan harus memenuhi persyaratan tersebut, baik pengetahuan, keterampilan, maupun kemampuan yang sesuai.

2. Kualitas pekerjaan

Setiap karyawan dalam perusahaan harus memenuhi persyaratan tertentu untuk dapat menghasilkan pekerjaan sesuai kualitas yang dituntut suatu pekerjaan tertentu. Setiap pekerjaaan memiliki standart kualitas tertentu yang harus disesuaikan oleh karyawan untuk dapat mengerjakannya sesuai ketentuan. Karyawan memiliki kinerja baik bila dapat menghasilkan pekerjaan sesuai persyaratan kualitas yang dituntut pekerjaan tersebut.

3. Ketepatan waktu

Jenis pekerjaan tertentu harus diselesaikan tepat waktu, karena memiliki ketergantungan atas pekerjaan lainnya. Jadi, apabila pekerjaan pada suatu bagian tertentu tidak selesai tepat waktu akan menghambat pekerjaan pada bagian lain, sehingga mempengaruhi jumlah dan kualitas hasil pekerjaan.

4. Kehadiran

Ada tipe pekerjaan yang menuntut kehadiran karyawan selama delapan jam sehari untuk lima hari kerja seminggu. Kinerja karyawan ditentukan oleh tingkat kehadiran karyawan dalam mengerjakannya.

5. Kemampuan kerja sama

Untuk jenis pekerjaan tertentu mungkin harus diselesaikan oleh dua orang karyawan atau lebih, sehingga membutuhkan kerja sama antar karyawan sangat dibutuhkan. Kinerja karyawan dapat dinilai dari kemampuannya bekerja sama dengan rekan sekerja lainnya.

\section{B. MODEL PENELITIAN}

Penelitian ini dilakukan di PT Angkasa Pura II Building 600, Soekarno-Hatta International Airport Jakarta 19120 Indonesia.

\section{Teknik Pengumpulan Data}

Dalam penelitian ini data diperoleh dengan menggunakan data dari PT Angkasa Pura II tahun 2018 dan 2019.

\section{Jenis dan Sumber Data}


Adapun jenis dan sumber data yang digunakan penulis dalam penelitian ini adalah menggunakan data sekunder.

\section{Metode Analisis Data}

Metode analisis data dalam penelitian ini adalah dengan menggunakan metode pendekatan deskriptif kualitatif.

\section{HASIL DAN PEMBAHASAN}

Berdasarkan Analisis, diketahui bahwa Sistem Kompensasi PT Angkasa Pura II pada Karyawan Bandara adalah sebagai berikut :

\section{Fixed Compensation}

Fixed compensation diberikan secara tetap baik bulanan maupun tahunan yang terdiri dari:
a. Gaji dasar pensiun
b. Penunjang gaji dasar
c. Tunjangan jabatan
d. Tunjangan hari raya keagamaan
e. Tunjangan kesejahteraan keluarga
f. Tunjangan cuti

\section{Variable Compensation}

Variable compensation diberikan secara tidak tetap namun diberikan berdasarkan persyaratan tertentu antara lain (kinerja, kehadiran, keterampilan, dan lain-lain) yang terdiri dari:
a. Insentif Produksi
b. Insentif Merit
c. Tunjangan uang makan
d. Tunjangan uang lembur
e. Tunjangan licence dan rating

3. Benefit yang berupa uang (cash benefit) terdiri dari:
a. Tunjangan mobilitas
b. Sumbangan uag sewa rumah
c. Tunjangan perumahan akhir masa tugas
d. Subsidi iuran badan penyelenggara jaminan sosial (BPJS)

4. Ketenagakerjaan 

a. Subsidi iuran tunjangan hari tua dan manfaat pensiun
b. Sumbangan perkawinan karyawan
c. Sumbangan kelahiran anak
d. Sumbangan kematian
e. Uang tanda penghargaan

5. Benefit yang berupa bukan uang (non cash benefit) terdiri dari:
a. Pelayanan kesehatan
b. Pakaian seragam dinas dan pakaian olahraga
c. Pengembangan karyawan
d. Promot life balance (olahraga, olah rasio, olah roh, dan olah rasa)

Dan pula menyediakan program dana pensiun dimana pensiun karyawan Angkasa Pura II ditetapkan pada usia 56 tahun. Bagi karyawan yang telah berusia 55 tahun dapat mengambil Masa Persiapan Pensiun (MPPP). Dalam Masa Persiapan Pensiun, Angkasa Pura II memberikan pelatihan wirausaha dan pelatihan purna bakti, sehingga diharapkan dengan para karyawan dapat mempersiapkan diri di masa mendatang.

Karyawan yang telah memasuki usia purna bakti (56 tahun), diberikan kompensasi sesuai peraturan. Sedangkan karyawan tetap yang diikutsertakan dalam Program Hari Tua (JHT) mendapatkan Kompensasi Jaminan Hari Tua sesuai Undangundang Ketenagakerjaan yang berlaku.

Jaminan Sosial dan Dana Pensiun termasuk dalam kompensasi, dimana keduanya diberikan sebagai timbal balik atas usaha yang telah diberikan kepada perusahaan. PT Angkasa Pura II sudah memberikan kompensasi yang cukup lengkap mulai dari Dengan kompensasi yang sudah diberikan, diharapkan karyawan dapat bekerja sebaik mungkin untuk kemajuan perusahaan.

Dan berikut Hasil Kinerja Karyawan dilihat dari sisi Operasional PT Angkasa Pura II

\begin{tabular}{|l|l|l|l|}
\hline Uraian & Growth & 2019 & 2018 \\
\hline $\begin{array}{l}\text { Pergerakan Pesawat (dalam } \\
\text { satuan Rute) }\end{array}$ & $-14,03 \%$ & 736.640 & 856.886 \\
\hline Pergerakan Penumpang (dalam & $-18,55 \%$ & 90.779 & 111.453 \\
\hline
\end{tabular}




\begin{tabular}{|l|l|l|l|}
\hline ribuan Pax) & & & \\
\hline Pergerakan Kargo (dalam Ton) & $-20,31 \%$ & 759.923 & 953.606 \\
\hline
\end{tabular}

\section{Tabel 1.1 Tabel Kinerja Operasional PT Angkasa Pura II}

Pergerakan pesawat pada tahun 2019 mencapai 736.640 rute didominasi penerbangan domestik sebesar 81,80\%. Jumlah pergerakan penumpang yang menggunakan jasa penerbangan di bandara-bandara Angkasa Pura II mencapai sebanyak 90,78 juta pax, dimana 78,38\% dari jumlah tersebut merupakan pergerakan penumpang domestik. Sedangkan pergerakan kargo tahun 2019, tercatat sebanyak 759,92 juta ton, dimana 53,49\% merupakan pergerakan kargo domestik. Pergerakan pesawat, arus penumpang dan kargo pada tahun 2019 menunjukkan peningkatan dibandingkan tahun sebelumnya.

\section{KESIMPULAN}

Dari hasil dan pembahasan di atas dapat disimpulkan bahwa:

Sistem Kompensasi PT Angkasa Pura II pada Karyawan Bandara adalah sebagai berikut :

1. Fixed Compensation

2. Variable Compensation

3. Benefit yang berupa uang (cash benefit)

4. Ketenagakerjaan

5. Benefit yang berupa bukan uang (non cash benefit)

PT Angkasa Pura II menyediakan dana pensiun bagi karyawannya yang berumur 56 tahun. Bagi karyawan yang telah berusia 55 tahun dapat mengambil Masa Persiapan Pensiun (MPP). Dalam Masa Persiapan Pensiun, Angkasa Pura II memberikan pelatihan wirausaha dan pelatihan purna bakti, sehingga diharapkan dengan para karyawan dapat mempersiapkan diri di masa mendatang. Karyawan yang telah memasuki usia purna bakti (56 tahun), diberikan kompensasi sesuai peraturan. Sedangkan karyawan tetap yang diikutsertakan dalam Program Hari Tua (JHT) mendapatkan Kompensasi Jaminan Hari Tua sesuai Undang-undang Ketenagakerjaan yang berlaku. Oleh karena itu, dapat disimpulkan bahwa PT Angkasa Pura II sangatlah memperhatikan karyawankaryawannya. Selain dengan kompensasi yang sebanding dengan kinerjanya PT Angkasa Pura II juga membuktikan hal tersebut melalui pelatihan kewirausahaan yang diberikan kepada karyawan pada Masa Persiapan Pensiun (MPP). 


\section{DAFTAR PUSTAKA}

Drs. H. Melayu S.P. Hasibuan. 2003. Manajemen Sumber Daya Manusia. Jakarta: Bumi Aksara,

Gerry Dessler. 2015. Manajemen Sumber Daya Manusia. Edisi ke empat.

Mangkunegara, Anwar Prabu. 2017. Evaluasi kinerja SDM. Bandung: PT. Refika Aditama,

Stefanus Andi,dkk. 2015. Pengaruh kompensasi terhadap kinerja karyawan.Jurnal Administrasi Bisnis.

Suwati,Y. 2013. Pengaruh kompensasi dan motivasi kerja terhadap kinerja karyawan pada PT Tunas Hijau Samarinda.E-Journal ilmi administrasi bisnis

Nawawi,H.2006.Evaluasi dan managemen kinerja di Lingkungan Perusahaan dan Industri. Penerbit Gadjah Mada University Press. Yogyakarta

Laporan Tahunan PT Angkasa Pura II tahun 2019. (Diakses pada tanggal 15 Juni 2020) Laporan Tahunan PT Angkasa Pura II tahun 2018. (Diakses pada tanggal 15 Juni 2020) https://www.angkasapura2.co.id (diakses tanggal 11 Juli 2020) 